\title{
ISLAMICATE CIVILIZATION AND NATIONAL ISLAMS: ISLAM \\ NUSANTARA, WEST JAVA AND SUNDANESE CULTURE
}

\author{
Mark Woodward \\ Arizona State University, Tempe, United States \\ E mail : MARK.WOODWARD@asu.edu
}

\begin{abstract}
Relationships between Islam and local cultures, post-coloniality, the construction of National Islams and nationalisms are extraordinarily complex. They pose complex academic, theological and political problems. This paper considers examples from the province of West Java in postcolonial Indonesia. It will be concerned with the ways in which elements of local West Javanese/Sundanese culture are rejected by Islamist nationalists but at the same time incorporated into a regional variant of the culture friendly Islam Nusantara formulated by Nahdlatul Ulama (NU) in 2015. See Chamami (2015) and Woodward (2018). It also suggests that what Philosopher of Science Karl Popper termed the "situational logic" of Islam Nusantara is based on principles that have driven the construction of what Historian Marshal Hodgson (1974) termed Islamicate Civilizations since they emerged in the sixth century.

Thorough consideration of these questions requires an overarching analytic and theoretical framework. Without one, we can produce disconnected, fragmentary analyses with limited practical applications. This paper is an attempt to establish such a framework. Building on Berger's constructivist approach to the Sociology of Religion, it draws on seemingly divergent
\end{abstract}


themes in the academic discourse about religion/society/state relationships in hope that the resulting synthesis will be of greater analytic utility and practical applicability than the sum of its parts. Empirically it focuses on West Java, Sundanese culture and emergence of alternative National Islams in contemporary Indonesia. It also makes comparative references to neighbouring countries, especially Malaysia. Theoretically, it is transdisciplinary, combining approaches from Cultural Anthropology, History, Political Science and Religious Studies. Given the current state of intra-Islamic political and religious discourse, it also necessarily focuses on debates between Sufi oriented "traditionalists" and Salafi oriented "modernists" that have been a major feature of colonial and post-colonial Muslim discourse for more than a century. It argues that alternative National Islams are shaped by a combination of theological debates and religion/state/society dynamics.

Keywords: Islam Nusantara, Progressive Islam, Islamicate, Sundanese culture

\begin{abstract}
Hubungan antara Islam dan budaya local, paska-kolonialitas, konstruksi Islam Nasional, dan nasionalisme sangat kompleks. Hal ini menimbulkan masalah akademik, teologis dan politik yang kompleks. Makalah ini membahas contoh-contoh dari provinsi Jawa barat di Indonesia di masa pasca-kolonial. Pembahasan disini terkait bagaimana unsur-unsur budaya Jawa Barat/Sunda local ditolak oleh nasionalis Islam tetapi pada saat yang sama dimasukkan ke dalam varian regional dari budaya ramah Islam Nusantara yang diformulasikan oleh Nahdlatul Ulama (NU) pada tahun 2015. Tulisan ini juga mengemukakan apa yang disebut oleh filsuf sains, Karl Popper, sebagai "logika situasional" Islam Nusantara didasarkan pada prinsip-prinsip yang telah mendorong konstruksi yang oleh sejarawan Marsekal Hodgson disebut sebagai Peradaban Islam sejak mereka muncul di abad ke-enam.

Pertimbangan menyeluruh dari pembahasan dalam makalah ini, memerlukan kerangka kerja analitik dan teoritis yang utuh. Tanpa satu dan lainnya, ini hanya dapat menghasilkan analisa parsial dan terputus-putus dan dengan aplikasi praktis yang terbatas. Tulisan ini merupakan upaya untuk membangun kerangka kerja seperti yang diharapkan diatas. Dibangun dengan pendekatan konstruktivis Berger terhadap Sosiologi Agama, tulisan ini menggunakan tema-tema yang nampaknya berbeda dalam wacana akademik tentang hubungan
\end{abstract}


agama/masyarakat/negara. Diharapkan sintesa yang dihasilkan akan memiliki kegunaan analitik yang lebih besar dan penerapan praktis yang holistik. Secara empiris, tulisan ini membahas Jawa Barat, budaya Sunda, dan munculnya Islam Nasional alternatif di Indonesia kontemporer, dengan juga membuat referensi komparatif ke negaranegara tetangga, terutama Malaysia. Adapun secara teoritis, pendekatan transdisipliner diterapkan dalam tulisan ini, dengan menggabungkan pendekatan Antropologi Budaya, Sejarah, Ilmu Politik dan Studi Agama. Mengingat kondisi saat ini terkait wacana politik dan antar aliran agama, pembahasan ini juga berfokus pada perdebatan antara "tradisionalis" yang berorientasi sufi, dan "modernis" yang berorientasi salafi yang telah menjadi fitur utama wacana Muslim masa colonial dan pasca-kolonial selama lebih dari seabad. Tulisan ini menyimpulkan bahwa alternative Islam Nasional dibentuk oleh kombinasi dari perdebatan teologis dan dinamika antar agama/negara/masyarakat.

Kata Kunci: Islam Nusantara, Islam Berkemajuan, Islam bercorak budaya lokal, Budaya Sunda

\section{Nationalisms: Post-colonialism, Institutions and the Imagined Communities}

Islam Nusantara emerged in the context of continuing debates about religion and nationalism that began in the late colonial era. There is a basic contrast between theories of nationalism by scholars including Gellner who stressed the centrality of institutions and institution building and others, of whom Anderson is the most influential, who emphasize the imagination of collective identities through the construction and manipulation of myths, rituals and symbols. (Anderson, 1983; Gellner, 1983) Both were opposed to the primordialist view that the nationalisms and derivative national identities are very nearly immutable and that their origins are lost in the depths of time. (Smith \& Woodward, 2016).

Gellner understood nations as social formations characterized by bureaucratic governance, technological communication, state 
controlled or regulated education in which citizens are replicable and replaceable in basic ways. He stressed the importance of civic values centered on protecting and aiding in the reproduction these social systems and held that ideologies are of secondary importance. He understood nationalist ideologies as forms of false consciousness no matter how deep their roots are.

Gellner was a constructivist, only to a limited extent. Anderson was much more of one and stressed the importance of nationalist ideologies and identities. In Imagined Communities, he observed that the nation is an imagined community in at least two ways:

.... because the members of even the smallest nation will never know most of their fellow-members, meet them, or even hear of them, yet in the minds of each lives the image of their communion. regardless of the actual inequality and exploitation that may prevail in each, the nation is always conceived as a deep, horizontal comradeship. Ultimately it is this fraternity that makes it possible, over the past two centuries, for so many millions of people, not so much to kill, as willingly to die for such limited imaginings. (Anderson, 1983)

Anderson took the position that nations are at once social and imagined realities. They are social realities to the extent they exercise relatively uniform control of a bounded space and the population inhabiting it. They are imagined communities to the extent that culturally and/or religiously salient symbols and narratives are manipulated in ways that lead very different people to believe that they share a common heritage that makes them sisters and brothers in a well-defined and bounded cultural community the borders of which are co-terminus with those of the geographic space of the nation state. This is what distinguishes nations form empires, which define themselves as 
political and economic, but not cultural realties. The emergence of nations within empires gave rise to post-colonial nationalisms.

Colonial and post-colonial nationalist narratives are often triumphalist and seek to imagine the possibility of a brighter future by retrieving the greatness and the cultural and/or religious distinctiveness of the past that was temporarily overshadowed by colonialism. This often takes the form of idealizing a semi-mythological past and ignoring oppressive social realities of precolonial states. The remembered/imagined grandeur of the past is often larger than life or history. (Vickers \& Fisher, 1999)

It may be the case that this re-imagination of history plays a central role the imagination of post-colonial states because it distances leaders and ordinary citizens from Western ideologies while retaining technological and administrative infrastructures inherited from them. Tambiah has shown that in Southeast Asia the new nations that emerged after the Second World War often discarded or at least subverted European ideologies in favor of traditional religious concepts and narratives in attempts to establish the cultural authenticity of the social realities of new states. (Tambiah, 1997) Chatterjee describes this process as follows:

The spiritual, on the other hand, is an "inner" domain bearing the "essential" marks of cultural identity. The greater ones success in imitating Western skills in the material domain, therefore, the greater one's need to preserve the distinctness of one's spiritual culture. (Chatterjee, 1986)

Revolutions, including the Indonesian Revolution of 1945, lend force to Anderson's statement that people are often willing to die for imaged communities. The West Java based Darul Islam movement is an example of how this principle operates in a revolution within a 
revolution. Kartosuwirjo proclaimed the movement in 1949 because he felt the revolutionary government of the Republic of Indonesia had betrayed its ideas and values by negotiating with the Dutch and withdrawing its forces from West Java. At one time, it controlled at least a third of West Java and large territories in Aceh and South Sulawesi. Darul Islam persist as Negara Islam Indonesia. Some members and former members still feel this "betrayal." (Formichi, 2013; Soebardi, 1983) For them, it has become a key symbol in an alternative nationalism. Each initiate swears an oath of allegiance and waits for orders. I learned of one man who is still waiting after being out of contact with the movement for more than thirty years. All of these examples pale before European cases, especially the First World War, in which the members of imaged communities founded on principles of inequality died by the hundreds of thousands to defend them. ${ }^{1}$

Anderson was a keen student of post-colonialism before the term was popular. He was a comparativist in a theoretical sense but was also explicitly concerned with the variety of ways in which Indonesia has been imagined from the late colonial period, to the post 1998 Reformation era. As is well known he supported revolutionary ideologies and social transformation of social and economic relations along Marxist lines. He looked on the Indonesian military and totalitarian tranquillity of Suharto's New Order with fear and loathing. He tended to see many of the positive, negative and indeed contradictory elements of modern Indonesian history as reflections of the interaction of elements of Javanese culture and Dutch colonialism. His views of Javanese culture were shaped by his experience in Central Java -- especially Surakarta. He did not write extensively about West 
Java or Sundanese culture. (Anderson, 1983)

The imagination of Indonesia, and of nations in general, is an ongoing process that is almost always contested and never finished. One of the critical junctures in the imagination of Indonesia was the October 28, 1928 Pemuda Indonesia (Young Indonesia) conference at which young leaders from diverse regional and ethnic backgrounds swore an oath to support the concepts of one people, one country and one language. (Foulcher, 2000) The question that was unanswered is: "Does this mean the obliteration of cultural differences or the emergence of a new shared culture that is an umbrella?" Nearly nine decades of historical experience tells us that it was the umbrella that emerged from the process. A case can be made that Suharto tried to subvert this process through his attempts to establish Central Javanese culture as politically hegemonic. (Sarsito, 2006; Woodward, 2011) Many Acehnese describe the New Order as "Javanese Imperialism." One of the tasks facing Indonesia today is to repair the tears in the umbrella. From the 1960s and into the 1980s there were debates about the reality of what Hildred Geertz called the "Indonesian metropolitan super-culture" rooted in consistent use of the Indonesian language, modern education, popular culture and contemporary Indonesian historiography or whether the concept of Indonesia was a thin veneer incapable of forestalling ethno-religious conflict. (H. Geertz, 1963) History has shown that Geertz was correct about the emergence of a new umbrella culture. It is equally clear that this did not prevent ethnoreligious conflict. It is, however, possible that in the absence of these cultural developments Indonesia could have gone to way of Yugoslavia and spiralled downward into ethno-religious war and national disintegration. ${ }^{2}$ 
Fisher-Omar, Liu and Woodward have attempted to resolve the differences between these theories of nationalism with a model describing the interaction of three components of nation states. (Liu et al., 2014) They require some modifications to capture the complexities of large, ethnically and religiously diverse nations such as Indonesia. The three components of the model are:

- Symbology-systems of symbolic meaning attached to and promoted by the state.

- Identity space - the groups and group identities that vie for legitimacy and control of state apparatuses.

- Technologies - the institutions and technological means used by the state to maintain and reproduce itself.

The concepts State Technology and Identity Space are strongly associated with Anderson's approach to the study of nationalism. State Technologies is more strongly connected with Gellner's. In Indonesia and other large ethnically and religiously diverse states there are multiple State Symbologies and Identity Spaces.

Officially Indonesia's identity space is defined on the basis of provincial and sub-provincial boundaries or lines on maps and is blind to religion and ethnicity. The underlying realities are more complex. ${ }^{3}$ Not all of Indonesia's identity spaces are reflected in provincial boundaries. Many are geographic and/or social spaces defined by territories and communities linked to pre-colonial kingdoms and/or Hindu divinities and Muslim saints. The $8^{\text {th }}-16^{\text {th }}$ century Sundanese kingdom of Pajajaran is an example. (Ricklefs, 2001) Like those of Majapahit in East Java, its state technologies vanished with the establishment of Islam. Religiously there are few survivors of its Hindu-Sundanese tradition Islamicized remnants of which are now 
known as Sunda Wiwitan. (Waluyajati, 2017) Nonetheless, it continues to define an identity space, especially in popular culture.

\section{Islam and Sundanese Culture}

Relationships between Islam and Sundanese culture are similar to those in neighbouring Javanese culture, but have been less thoroughly studied. Muslim saints (wali) and kings were instrumental in the establishment and spread of Islam in the $16^{\text {th }}$ century. (Guillot et al., 1990) Sundanese culture retains mythic, literary and ritual forms derived from Hindu and indigenous traditions. One example is the popular poetic tradition known as pantun. Some pantun describe the days of Pajajaran as a golden age in which famine and debt were unknown. It would, however, be mistaken to think of this tradition as a fossilized version of the pre-Islamic past. It also brings elements of pre-Islam culture and religion into Islamicate Civilization. Weintraub provides this pantun concerning Nyai Pohaci Sanghyang Asri as an example:

Clearly, I face toward the Almighty

I arrive to face the all-powerful

By the request of the Prophets

Allah called by the essence of Allah

Comes the essence, the feeling

Clearly, I face toward the Almighty

I arrive to face the all-powerful

By the request of the Prophets

Allah called by the essence of Allah

Comes the essence, the feeling

To enter the gate of heaven

The one following Allah Cunia Maniko

More incense burns

Gloriously entering Pohaci's body

Sangian Sri

Trusting into Sangian Naga

Coming to Susunan Rama

The arrival of the true Pohaci

To enter the gate of heaven 


\section{The one following Allah Cunia Maniko}

More incense burns

Gloriously entering Pohaci's body

Sangian Sri

Trusting into Sangian Naga

Coming to Susunan Rama

The arrival of the true Pohaci. (Weintraub, 1994)

Smith and Woodward have shown that elements of the divine feminine rooted in indigenous and Hindu traditions survived the transition to Islam in both myth and ritual throughout Java and many other parts of Indonesia. (Smith \& Woodward, 2016) Pohaci is the Sundanese rice "goddess" and resembles the Javanese Dewi Sri in many respects. (Hidding, 1929; Robert Wessing, 1988) She is the village modality of the feminine divine and is symbolically linked to water and snakes. She is a source of agricultural abundance and wealth derived from the earth in a more general sense. She plays a major role in Sundanese creation myths that survived the transition to Islam in the $15^{\text {th-16th }}$ century. According to these legends Pohaci was originally a beautiful widadrai (nymph) and Bhatara Guru's (Siva, the king of the gods) step daughter. The other gods poisoned her to prevent his sexual attraction to her from leading to incest. Because of her virtue and chastity rice emerged from her navel and other agricultural plants including the coconut tree and spices and those used for construction materials (bamboo and teak trees) from other parts of her body. There are rituals honoring her and asking for her blessing throughout the agricultural cycle. (Iskandar \& Iskandar, 2017) Some myths state that Nyai Ratu Kidul, the queen of the Southern Ocean is her sister. Ratu Kidul is the royal modality of the divine feminine. She is associated with mineral wealth in the form of exchange value (gold and silver), military and magical power. She is said to have married Panembahan 
Senopati, the founder of the central Javanese Maram dynasty and his descendants in Yogyakarta and Surakarta. Rituals honoring and seeking her aid and protection are held along the south coasts of East, Central and West Java. (Jordaan, 1997; Woodward, 1989)

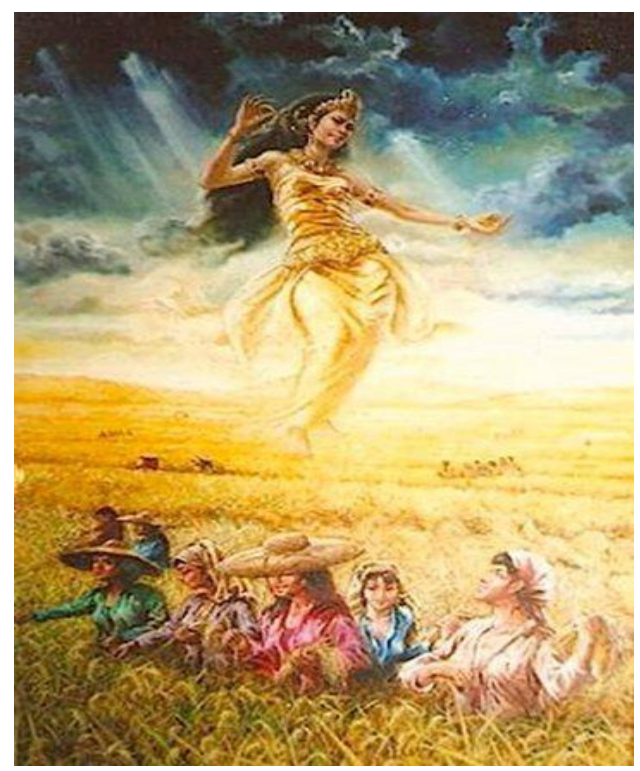

Nyai Pohaci Sanghyang Asri

The invocation of Allah, Muhammad and other Muslim prophets makes is clear that this pantun is simultaneously Sufi poetry and a literary device for bringing an element of Sundanese culture into an emerging Islamicate Civilization. The fact that pantun is a village based oral performance tradition indicates that it not only a mode of Sundanese Sufi literature, but as a media for dakwah (propagation of Islam) at the village level. (Millie, 2009; Rohmana, 2012)

The $15^{\text {th }}$ century Muslim saint Sunan Gunung Jati provides another example. He was one of the Wali Songo, the nine saints instrumental in establishing Islam as the religion of Java. (Rinkes, 
1996; Sunyoto, 2016) His genealogy connects historical and contemporary Sundanese identity symbologies and spaces by tracing Sunan Gung Jati's ancestry to the Prophet Muhammad through his father and Prabu Siliwangi, the last Hindu king of Pajajaran, through is mother. He was instrumental in establishing the Sultanates of Banten and Cirebon, both as a conqueror and as a Muslim member of a Hindu royal family. ${ }^{4}$ According to some accounts that may be revisionist histories designed to push the Muslim history of West Java further into the past that can be justified on the basis of existing sources, Prabu Siliwangi converted to Islam.

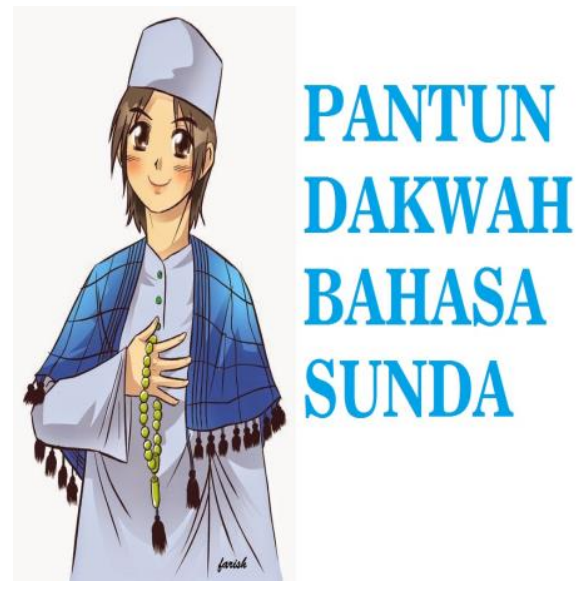

Pantun as Dakwah

His grave in Cirebon is a popular pilgrimage site. For most pilgrims, especially those on organized Wali Songo tours, it simply one of a large number of sites at which barakah (blessing) can be obtained. But, as McKinley and Woodward have noted saints and their graves define territories and social communities, ranging from villages to kingdoms. (Woodward, 2014) In the case of the Wali Songo and other founding saints they also define symbologies. In Java, and elsewhere in 
Indonesia, pre-Islamic divinities and traditions are transformed in ways that make them compatible with Islam and incorporated into these symbologies. This is what Abdurrahman Wahid (Gus Dur) called the pribumisasi (indigenization) of Islam.

There are many other similar cases elsewhere in West Java and throughout Indonesia in which the pre-Islamic past is not regarded as something to be cast aside, but rather as a cultural inheritance (warisan kebudayaan) that must be treated with respect. Especially with the introduction of a religion, such as Islam, that defines a global identity space, collective cultural memories are important for establishing and maintaining local identities. ${ }^{5}$

Most nation states have similar alternative identity spaces. From this we may conclude that nation states, or at least successful ones, have no choice other than to be cognizant and tolerant of identity spaces other than those of their own creation. This is an especially critical issue in democratic states in which electoral choices are not necessarily defined entirely by state based identity spaces. Much the same can be said of State Symbologies. While all states perceive for the need of official or semi-official symbols -- in the case of Indonesia Pancasila-- there are often equally powerful symbologies that lie beyond state control. ${ }^{6}$ Religion is an especially important example because it is more than a set of symbols. It is also a core set of convictions about the world we live in, how we are to conduct ourselves in this life and what the consequences of our conduct will be in the life or lives to come. States that trample on alternative religious symbologies do so at their peril and are unlikely to succeed. The resurgence of religion in the former Soviet Union and post-communist China shows. Alternative symbologies can be persecuted and driven underground but their proponents are so dedicated to them that it is 
unlikely they can be eliminated. Indonesia's choice of Bhinneka Tunggal I $k a$ (Unity in Diversity) as a national motto was a wise decision. Since the collapse of the New Order in 1998 there has been a strong interest in political decentralization and in the preservation and cultivation of kearifan lokal (local wisdom). (Bell, 2001; Holtzappel \& Ramstedt, 2009; Reuter, 2009) A quick Google search yielded hundreds of academic and journalistic articles base on this subject. The term kearifan lokal is used in many ways and in many contexts. Local wisdom concerning ethics and social justice can be found in oral traditions such as pantun that embody generations of collective memory. The continuing expansion of what Hildred Geertz called the "metropolitan super-culture" and the development of information technology, which did not exist when she coined the term, makes it possible for this wisdom to be shared outside the communities in which it originated. It has become a conceptual framework for understanding and valuing non-Muslim aspects of Islamicate Civilization.

The Indonesian discourse about alternative symbologies and local wisdom does, however, tend toward utopianism. To suggest that the affirmation of local knowledge necessarily promotes wisdom and justice leads to the philosophical blunder of idealizing Rousseau's musings about the virtues of the "Noble Savage." 7 There are also alternative symbologies defining ethnic and religious others as inherently evil, existential threats. Left unchecked, these local teachings lead to persecution and outbreaks of communal violence. The Indonesian Front Pembela Islam Islamic Defenders Front/FPI) is a case in point. FPI uses fear, demonization and hate speech outside Indonesia's state symbology to promote violence against Syiah and 
Ahmadiyah Muslims and other minorities. (Woodward, 2014) Managing groups promoting this sort of alternative symbology is an enormous, long-term challenge. Islam Nusantra, properly understood, affirms local wisdom, and at the same time locates it within a universal value system rooted in Muslim concepts of justice and mercy.

\section{Islamicate Civilizations}

The history of Islam and its incorporation into and transformation of local cultures is a complex field of study in which there have been contentious debates both among academic scholars and Muslim scholars (ulama). This has often been a highly polemical theological and political discourse. Some, including colonial scholars such as Landon, Raffles and Van Leur and others who followed in their footsteps including Geertz and Beatty have argued that in Indonesia Islam is a "thin veneer" resting on the surface of more deeply rooted animistic or Hindu-Buddhist civilizations. (Beatty, 1999; C. Geertz, 1960; Landon, 1949; Raffles, 1817) Wessing framed Sundanese Islam in similar ways. (R Wessing, 1974)

Modernist and Islamist Muslim thinkers in Indonesia and elsewhere have similar views and sometimes cite Geertz as an academic authority supporting their theological positions. In the late 1970s Muhammadiyah sermons that mentioned Geertz, as well as the Qur'an, as proof texts that Javanese culture and traditional Indonesian Muslim religious practices are not properly Islamic. Today Geertz is cited as an authority in hundreds of Indonesian web postings. This was, and remains, a strange sort of reverse Orientalism. Others including Florida and Woodward have argued that legends and symbols based on pre-Islamic sources have, for the most part, been absorbed and reshaped in the formation of what Hodgson called an "Islamicate 
Civilization." (Florida, 1995; Woodward, 1989) Indonesian and other Southeast Asian Muslim traditionalists including Wahid, Muhaimin and Alatas express similar views. (Alatas, 1997; Muhaimin, 2006)

Hodgson used the term Islamicate Civilization to refer primarily to "high" or elite cultural products - literature, science, philosophy, monumental architecture and to institutions including Shari'ah courts and Sufi orders developed in societies in which Islam is the primary religion and frame other aspects of cultural development. As an Anthropologist, I have more egalitarian view and consider "popular" ritual, historical and performance traditions, including veneration of the Prophet, saints and religious teachers and local historical texts to be elements of these same civilizations. In Indonesia, the religious and political elites Hodgson references were also devotees and participants in these traditions. High traditions, especially chronicles and state ceremonies have also influenced the development of village and increasingly urban level tradition and Muslim practice. (Woodward, 2011)

Again, speaking as an Anthropologist, it is essential to maintain a clear distinction between academic and confenssional perspectives. It has long been common practice for Salafis, including those associated with Persatuan Islam that is especially influential in West Java, to describe traditional Muslim devotional traditions such as pilgrimage to the tombs of saints (ziyarah), as bid'ah (innovation in religious matters) and shirk (polytheism). Similarly, traditional Muslim scholars argue that they are Islamic and that their Salafi opponents are simply wrong. ${ }^{8}$ The narrative structures and semantics of these competing symbologies and the emergence of social formations including political parties and other mass organizations are academic and political topics 
of enormous importance. Weighing in on them in normative ways is a different sort of intellectual exercise. The first religious discourse, the second discourse about religion. ${ }^{9}$

Hodgson focused this attention on Arabic, Persian and Turkish Islamicate Civilization. He is highly critical of Geertz's tripartite abangan-priyayi-santri (Animist-Hindu-Islamic) typology, observing that many of the religious beliefs and practices Geertz describes as Animist or Hindu-Buddhist are actually Islamicate traditions, many of which are shared across a wide range of Muslim cultures. The specification of civilizational boundaries is a difficult task for a number of reasons. What follows is a general consideration of these issues focusing on Southeast Asian cases.

- Civilizational boundaries are fuzzy. It is sometimes not easy to say which groups or individuals should be located where. Some can be located within multiple civilizational complexes. Hadhrami Sayyids are an example because to varying degrees they are located within national, regional Southeast Asian Arab and an encompassing Hadhrami diaspora that extends around the Indian Ocean litoral civilizational spheres.(Ho, 1997)

- Like ethnicity, civilization is a hierarchical concept. ${ }^{10}$ One can, for example, think of Sundanese and Javanese Islamicate civilizations. At a higher level of specificity, it is possible to distinguish between East and Central Javanese. At a still greater level of specificity the kingdoms/cities of Yogyakarta and Surakarta are very different places. I do not know West Java well enough to speak with certainty about the subcategories of Sundanese Islamicate civilization but am willing to make a theoretically driven prediction that they exist. At a more inclusive level it is clear that West Sumatran and Malaysian Minangkabau, Johor Malay, Sundanese, East and Central Javanese cultures share can be understood as a higher-level trans-ethno-linguistic Islamicate Civilization. Here, it is illuminating to compare (Skeat, 1900) Malay Magic with Geertz's (1960) Religion of Java. The lists of "magical" practices included in these works correspond very closely. (C. Geertz, 1960; Skeat, 1900)

\section{- Universalist, Essentialist and Local Islams}

The discussion of Islamicate Civilizations is congruent with that 
of the distinction between universalist and local Islams that has informed the anthropological study of Muslim cultures for decades. At issue here are relationships between the scriptural foundations of World Religions and the ways in which they are interpreted and practiced in cultural and historical contexts. They apply to all religions that cut across ethnic and cultural boundaries. They are as relevant to Buddhism, Christianity and Judaism as they are to Islam. (Bellah, 1991) Even within religious organizations bound together by wellestablished educational systems, culture is an enduring factor in the ways in which religion is lived and experienced. Muhammadiyah is an example. It's two strongholds are West Sumatra and Yogyakarta in Java. Despite a common core of theological and social teachings the two Muhammadiyahs are quite different as lived Islams. ${ }^{11}$ For example in West Sumatra, the Minangkabau matrilineal kinship produces a very different religion-culture dynamic than the bilateral Javanese system in Yogyakarta does.

For more than a century, Minangkabau Muhammadiyah leaders including Hamka and his less famous, but equally influential father Haji Rasul, actively struggled against this aspect of Minangkabau culture. (Hamka, 2010; Rush, 2016) Inheritance is less of an issue in Yogyakarta. There, some people who are deeply committed to the establishment of Shari'ah avoid inheritance issues by making certain that property is divided on the basis of gender equity principles by distributing it prior to death. Other Indonesian Muslims who I have discussed with this matter in Lombok made this point quite forcefully explaining that Allah created humans as equal and that matters such as inheritance are cultural.

There is an extensive literature concerning relationships between 
what Geertz called scripturalism and classical styles. (C. Geertz, 1968)

Eickelman phrased these issues in the following terms.

The main challenge for the study of Islam in Local contexts is to describe and analyze how the universalist principles of Islam have been realized in various social and historical contexts without presenting Islam as a seamless essence on the one hand or as a plastic congeries of beliefs and practices on the other.(Eickelman, 1982)

With an eye towards furthering these discussions and developing more powerful analytic tools for capturing the complexity this discourse I developed a four-level classification system twenty years ago. (Woodward, 1989) This system now requires further elaboration to address issues Islamicate Civilization and national Islams.

- A very limited Universalist Islam that would include the Qur'an and the five pillars of faith. This is a vexing issue because while there are many claims about what should be included there is no consensus among Muslims even concerning the Hadith because the Sunni and Syiah have different collections. It is, therefore, necessary to keep the list as short as possible.

- A much more expansive Essentialist corpus including the Hadith collections and the foundational texts of Sunni and Syiah legal schools and a large corpus of theological and mystical texts and associated rituals. Here I build on Eickelman's observation that within and across local contexts, it is essential to pay greater attention to the vicissitudes of the textual tradition.

- Received Islam, by which I mean the portion of the Essentialist corpus present in a particular physical or social space. This includes ritual and social practices as well as texts. I was struck by the importance of including ritual practice when I visited a Sufi shrine in Niger, West Africa. When I visited the founder's grave my guide and companion explained that on Thursday evenings after the maghrib prayer many people visited (he used the term ziyarah) the grave and recited "parts of the Qur'an). I asked: "Do you mean Surah Yasin?" He asked: "How did you know?" I replied: "Because that is what we do in Indonesia?" And regarding social practices: We left the shrine, returned to the Syech's house and had a meal similar to those I have often had with Javanese kyai: yellow rice, roasted goat, cucumbers, tomatoes and tea. This was perhaps the most illuminating encounter I have had in forty years of studying Islam local contexts.

- Local Islam that is the product of the interaction of Received Islam and local cultures. Here it is also necessary to consider issues of class and power as well as culture if we are to understand the variation among imperial, peasant, and urban formulations local religion in 
any given context.

There is a distinction between those who insist on what they understand to be a "literal" understanding of the Qur'an and Hadith and view alternatives as being heretical innovation and others who accept change and development as vital features of Islam as long as they are in accord with and enhance basic Islamic principles. For most of the history of Islam, those advocating the second perspective have been the most powerful voices. For more than a century, debate between proponents of these views of the relationship between religion and culture should be has been a central theme in transnational Muslim discourse.

Advocates of the Islamisization of culture and the Indigenization of Islam make use of this conceptualization in very nearly opposite ways. Again, it necessary to distinguish academic and ideological/theological uses of this concept. For example, it is sometimes said that: "To be Sundanese is to be Muslim." This phrase has often been used as an ideological-theological construct. It is also an ambiguous concept because it can be interpreted as meaning either:

- Sundanese culture is by definition Muslim. This is an affirmation of the Islamic authenticity of culture. It is expressed in the proverb, "Islam teh Sunda, Sunda teh Islam" (Islam is Sunda and Sunda is Islam.)

- Sundanese culture is not Islamiclly authentic and must be brought into conformance with Islamic norms. This is the view of Persatuan Islam and other modern Islamist organizations.

Both statements are pious fictions because there are ethnic Sundanese such as Baduy who are not Muslims and continue to practice only Sunda Wiwitan. The fusion of ethnic and Islamic identities is carried even further in Malaysia where there is a legal fiction that all Muslims are Malays and all Malays are Muslims. To convert to Islam is also to 
become a Malay. Thus, the ideological construct is that if am ethnically Chinese or Indian Malaysian converts to Islam she or he shifts ethnic as well as religious identities.

\section{Islamicate Civilization and Colonialism}

Prior to the consolidation of colonial rule in the early to mid $19^{\text {th }}$ century the territories that now comprise Indonesia, Malaysia, Brunei Darul Salam and southern regions of the Philippines and Thailand included a vast array of traditional states linked by trade, traditions and networks of Muslim scholars and students. This was an Islamicate Civilization on par with any of those Hodgson describes. This was a civilization dominated by various forms of Sufism and accommodationist, inclusivist pproach to local culture. (Johns, 1961; Ricklefs, 2006) It had strong ties with Arab Islamicate civilizations through the haj and the Hadhrami diaspora. (Ho, 1997; Laffan, 2007; Sirriyeh, 1999)

One of the most important religious developments during the colonial period were the introduction of the Egyptian modernism associated with Muhammad Abduh and Salafism. (Alatas, 2008; Azra, 2004; Noer, 1973) Both called on Muslims to "return to the Qur'an and Hadith" -- but understood this call is very different ways. Muhammadiyah, Indonesia's largest organization has generally sought to accommodate local cultures, partly because it has always stressed education and health care, though more so in Java than Sumatra. Others including Sumatran Muhammadiyah leader Haji Rasul (18791945) and Persatuan Islam founder Ahmad Hassan (1887-1958) were unrelenting in their opposition to anything that they considered to be bid'ah (religious innovation) or syirik (polytheism) and local culture. For present purposes, what is important is that the arrival of these new 
religious orientations permanently altered Southeast Asia Islamicate civilizations. (Djamal, 2014)

Questions concerning Islamic authentic moved from the periphery to the core of Southeast Asian Muslim discourse. When reformism came to Southeast Asia in the early twentieth century it appealed largely to segments of the population concerned with the Western hegemony and the perception that Muslims had fallen behind in scientific and technological fields. They offered a combination of modern education and religious reform as a solution. The Egyptian scholar Muhammad Abduh (1849-1905), whose thought influenced the development of Muhammadiyah in Java and the kaum muda (young group) in Sumatra and Malaya, combined these agendas with an intellectualized form of Sufism purged of what he held to be superstitious elements. (Hourani, 1962) His student and selfproclaimed spiritual heir Rashid Rida (1865-1935) who was influenced by Wahhabi teachings, took a much stronger anti-Sufi position. Rida was at least as influential in Southeast Asia as his mentor Abduh. (Bluhm, 1983) In the 1920s and 1930s he published a series of virulent critiques of Sufism in his journal al-Manar, which circulated widely among Southeast Asian reformists and that were echoed and sometime quoted in Southeast Asian publications including the Yogyakarta magazine Suara Muhammadiyah and al-Iman, a kaum muda journal published in Singapore between 1906 and $1908^{12}$ Persatuan Islam, Muhammadiyah, al-Irshad and other reformist groups share his views. Many traditionalists, including the founders of NU, embraced calls for educational modernization, but were and are unalterably opposed to Rida's anti-Sufism. (Woodward, 2011)

Much of the debate about Islamic authenticity revolves around the 
question of bidah (innovation). Indonesian modernists follow Ibn Tamiyyah (1263-1328) and al Wahab (1703-1792), both of whom considered any innovation in ritual matters to be unacceptable. This led them to condemn practices such as prayers for the dead (tahlil), pilgrimage to the tombs of saints (ziarah) and veneration of the Prophet Muhammad, which are basic elements of Sufi piety. (Meijer, n.d.; Memon, 1976) These positions are based on what their proponents regard as literal readings of the Qur'an and Hadith. Most other Muslim scholars, including those of the Shafi'i legal school that is predominant in Southeast Asia interpret the Qur'an and Hadith differently and consider reformist views to be heretical innovations. They distinguish between beneficial (hassana) and reprehensible (dalala) innovation. (NU Online, n.d.)

Hasyim Asy'ari, one of the founders of the traditionalist Nahdlatul Ulama, articulated the traditional position in the inaugural issue of Swara Nahdlatul Ulama (The Voice of Nahdlatul Ulama). He subsequently accused modernists of reprehensible bidah writing:

They wander the face of the earth spreading enmity and hatred. They tell lies about God even though they know the truth. (Mahmud, 2008)

Debates concerning the powers of saints, their ability to intercede with Allah on behalf of their devotees and intercessory prayers for the dead were, and sometimes still are, equally caustic. All parties to these debates cite the Qur'an and Hadith in support of their positions. Traditionalists also cite classical Arabic texts on Islamic theology and law or what I have described here as Essentialist Islam in support of their positions. (Maskumambang, 2015)

Colonial policy shaped the ways in which these developments were received in what are now Indonesia and Malaysia. In the 
Netherlands Indies, the Dutch were not overly concerned about theological developments and controversies so long as they did not have political implications. They met with very different responses in British Malaya. In the Netherlands Indies Muhammadiyah, the largest modernist movement was established in 1912. Nahdlatul Ulama, the largest traditionalist movement, and the one that best represents premodern Southeast Asian Islamicate Civilization was founded in 1926. The Dutch were at willing to tolerate these developments. There were no similar developments in the indirectly administered portions of British Malay. The terms of the treaties on which colonial rule was based left control of religion (Islam) and custom (adat) in the hands of the Sultans. They were, justifiably concerned that the spread of modernist/Salafi teaching and even the development of traditionalist mass organizations would undermine their already limited authority. The exception that proves the rule is that the directly administered Straights Settlements (Malacca, Penang and Singapore) became centers modernist/Salafi teachings. (Noorhaidi Hasan, 2006) The boundary between Dutch and British colonial empires was porous. Reformist ulama moved freely between Sumatra and peninsular Malaya. Cross Malacca Straights relationships are still close. Malaysian families with kaum muda orientations often chose to send their children to modernist schools in Sumatra because the type of Islamic education they provide is not available in Malaysia.

\section{Trans-national and National Islams}


The concept of National Islam that explicitly references local cultural contexts and local Islams is a relatively new one. It emerged in response to the global spread of am especially intolerant Second Wave Salafism beginning in the 1980s. (Roy, 2010; Woodward et al., 2013) In Indonesia Second Wave Salafism was centered in the tarbiyah (education) movement on secular university campuses. Dewan Dakwah Islamiyah promoted it with considerable financial assistance from the Saudi Arabian and Kuwaiti governments and private foundations. LIPIA (Lembaga Ilmu Pengatahuan Islam dan Arab/ Institute for Islamic and Arabic Studies) serves as a channel for sending funds to Indonesia and also provided scholarships for Indonesia students to study at Saudi Islamic Universities. (Hasan, 2007; Machmudi, 2008)

In general, Second Wave Salafisms embrace various combination of Muslim Brotherhood activism and Salafi-Wahhabi religious teachings and cultural practices. (Hasan, 2008) There is a strong tendency to embrace what Roy calls de-culturalized Islam. (Roy, 2010) Exactly what this means varies significantly from individual to individual and from group to group. Many adopt pseudo Saudi clothing styles and other cultural practices. Some I have spoken with explicitly renounce ethnic (Javanese) and national (Indonesian) identities. One young man I spoke with at Gadjah Mada University stated: "I am not Indonesian, I am not Javanese, I am only Muslim.” (Woodward, 2017)

The political orientations of groups emerging from the tarbiyah movement vary greatly. Some live in pious isolation, distancing themselves from what they deem to be an irredeemably corrupt world. There are now a number of pesantren that promote this view. At these pesantren there is no secular education. Some, including Pondok Pesantren Imam Bukhari in Solo, attract students from across 
Indonesia and from Malaysia and Singapore. There are others with similar religious orientations that are highly socially engaged. The tarbiyah movement also gave rise to Partai Keadilan Sejahtera (PKS), which is actively engaged in electoral politics and Hizbut Tahrir Indonesia, which describes itself as a political party but rejects participation in elections as being counter to Islamic teachings.(Ahnaf, 2011; Woodward et al., 2013) Still others have moved in the direction of armed struggle to establish either and Indonesian Islamic state or a regional or global Caliphate. (Hasan, 2008)

Interest in, and concern with an Indonesian National Islams emerged in response to these developments. The publication of Ilusi Negara Islam (The Illusion of the Islamic State) edited by Abdurrahman Wahid of NU and Syafii Maarif of Muhammadiyah in 2009 was a critical point in this process. (Wahid, 2009) It marked the beginning of a new era of cooperation between Indonesia's largest Muslim organizations, the traditionalist Nahdlatul Ulama and the modernist Muhammadiyah.

Since that time both NU and Muhammadiyah actively pursued National Islam agendas, though in different ways. Muhammadiyah introduced the concept of Islam Berkemajuan (Progressive Islam) and NU promotes Islam Nusantara (Archipelagic Islam). Both are based the idea that Indonesian Islam is unique because it accepts culture and promotes intra-Islamic pluralism. Both organizations assert that Indonesian Islam can be a model for the world. A message posted on Indonesian President Joko Widodo's website on February 28, 2016 praised NU and Muhammadiyah for their contributions to Indonesia's development and for their insistence that Islam and nationalism are inextricably bound together. He continued that collectively their efforts 
show that Indonesian Islam can make important contributions to global efforts to build the peace and prosperity. ${ }^{13}$

On closer examination is clear that in developing Islam Nusantara and Islam Kemajuan the two organizations have simply reframed positions that they have taken since the early $20^{\text {th }}$ century. Islam Nusantara is a steadfast defense of Muslim tradition that accepting of local culture in general Southeast Asian Islamicate Civilization in particular. Looking more closely this means reaffirming the authenticity of Islam in East Java and Madura with its reverence for the Wali Sanga and validation of ritual practices such tahlil and ziyarah. At the same time it calls for tolerance, respect for others, culturally sensitive and minimizing potentially disruptive disputes about fiqh and aqidah. NU General Chairman Agil Siraj put it this way: "This is not a mahdzab (legal school) or sectarian group ..... Islam Nusantara is Islam fused with culture." In response to critics Muhajir has made it clear that there are universal aspects of Islam including the fundamentals of Aqidah (Belief in Allah and his Angels, Holy Books and Prophets, the last Day and Divine decree) that are not subject to change and to not vary from one place to the next. ${ }^{14}$

An important question is: Which culture(s)? If the sole, or even primary, cultural reference point is the East Java/Madura NU heartland, there is only a slight chance that Islam Nusantara will become more than a venue for promoting long established NU values and traditions. How are Indonesian Muslims including those from West Java, let alone the substantial number of Muslims whose cultures are more distant from Java than the Sundanese to be brought under the umbrella without alienating core supporters? These are issues that remain to be addressed. It requires a more general reformulation of the 
philosophical basis on Islam Nusantara along lines suggested by Hodgson.

Muhammadiyah's Islam Berkemajuan has a universalist, economic development orientation. It is also referred to as a gerakan pencerahan (Enlightenment Movement). The guiding principles of Islam Berkemajuan are religious universalism, ethics and economic development with the objective of building a just Islamic society. Numerous commentators have stated that it is a continuation of the agenda Ahmad Dahlan staked out when he established the organization in 1912. Muhsin Hariyanto of the Muhammadiyah University in Yogyakarta has written that:

These ideas are rooted in those of KH Ahmad Dahlan and KH Mas Mansur. To be truly progressive Muslims must be progressive in all ways. It is necessary to break free of the minority mentality that holds them back. We must stress the role of Islam in the development of ethics and the economy. This will make the economy just and profitable for everyone involved.

He outlined a three-point program for the realization of these goals:

- The rapid, progressive transformation of systems, organizations and networks to make them advanced, professional and modern.

- The development of high quality, independent charitable movements capable of supporting the establishment of a genuinely Islamic society.

- Development of Muhammadiyah's strategic role in the lives of the people, the nation and in global dynamics. ${ }^{15}$

As the Islamist tabloid Suara Islam has noted, there is very little that can criticized in this agenda because it does not touch on controversial religious issues. ${ }^{16}$ Muhammadiyah does not mention it's neo-Salafi religious program when discussing Islam Berkemajuan. It does not need to because its religious institutions are not under assault. 
There are, however, at least two questions that have not been addressed. The first is that this urban, business oriented agenda may be simply irrelevant for most Indonesians. The second is that Muhammadiyah has advocated this agenda for more than a century with questionable results. Muhammadiyah has, however, taken steps to make it very clear that it is not opposed to Indonesian cultures in the ways that other organizations tracing their theological roots to Ibn Taimiyyah. Writing in Suara Muhammadiyah, Haedar Nashir is generally supportive of Wahhabi efforts to "purify" Islam. He is at the same time critical of the harsh and often violent methods Saudi Arabian Wahhabis have used to accomplish this goal. He is also critical of Wahhabi claims that theirs is the only authentic Islam. He observes that:

There is no perfect interpretation of Islam or Islamic movement that is entirely perfect. They are always exposed to the law of relativity. Even moderate groups, including those that accommodate local culture, are not manifestations of Islamic perfection, especially when preserving traditional forms that are contrary to the main principles of tauhid (the unity of God) and holding the spirit of Islamic progress. There is no perfect actualization of Islam on this earth. What is most important is trying to show the depth and breadth of the teachings of Islam throughout the ages. The perfection and breadth of Islamic teachings necessitates a consistent manifestation accompanied by equivalent spiritual, intellectual, institutional and infrastructure devices so that Islam appears as din al-hadharah (religion of civilization, religion of progress). ${ }^{17}$

Nashir is implicitly critical of Islam Nusantara because it does not share Muhammadiyah's emphasis of "purification." He is, at the same time, supportive of its basic principle of recognizing the authenticity of culturally and historically specific interpretations of Islam.

\section{Conclusions}


The prospects for the emergence of a unified Indonesian Islam are not great. Theological, cultural and class differences as great as there are in Indonesia would be difficult to unify. But there is a difference between unification and mutual recognition. Leaders from Muhammadiyah and NU and Muhammadiyah have worked together and behind the scenes for decades. The close working relationship between Abdurrahman Wahid and Syafii Maarif is a paradigmatic example. Today, leaders of both organizations see Islam Nusantara and Islam Kemajuan as complimentary aspects of Islam Wasathiyah or Middle Path Islam that opposes extremist tendencies of all sorts. This social agenda is often referred to as "Islam Nusantara Berkemajuan."

On August $26^{\text {th }}$ 2016, the herbal medicine firm PT Bintang Toedjoe offered to facilitate NU and Muhammadiyah jointly conducting the feast of sacrifice in which cattle, sheep and goats are slaughtered the meat distributed among the poor. Such practices are not unknown but are unusual. What was unusual was the message that came with the proposal.

Hopefully with this shared sacrifice, the spirit of togetherness will be maintained. If $N U$ has the concept of Islam Nusantara, and Muhammadiyah Islam Berkemajuan then it can move together into Islam Nusantara Berkemajuan. (NU Online, n.d.)

This is a striking example of what Diana Eck of the Harvard Pluralism Project calls Civic Pluralism. (Eck, 2007) It does not require coming together on fundamental religious issues. It is rather people with differing faith convictions working together to achieve common goals. This is the vision of Islam that President Joko Widodo has proposed as be a model for other Muslim societies.

\section{References}


Ahnaf, M. I. (2011). From Revolution to "Refolution” A Study of Hizb al Tahrir, Its Changes and Trajectories in the Democratic Context of Indonesia (2000-2009).

Alatas, S. F. (1997). Hadhramaut and the Hadhrami Diaspora: Problems in Theoretical History. In: Freitag, W. (Ed.), Hadhrami Traders, Scholars and Statesmen in the Indian Ocean 1750s-1960s. Leiden: Brill.

Alatas, S. F. (2008). Muslim reform in Southeast Asia: Perspectives from Malaysia, Indonesia and Singapore. Singapore: Majlis Ugama Islam Singapura.

Anderson, B. R. O. G. (1983). Old State, New Society: Indonesia's New Order in Comparative Historical Perspective. The Journal of Asian Studies, 42(3), 477-496. https://doi.org/10.2307/2055514

Azra, A. (2004). Review: Islamic Nationhood and Colonial Indonesia: The Umma below the Winds * Michael Francis Laffan: Islamic Nationhood and Colonial Indonesia: The Umma below the Winds. Journal of Islamic Studies. https://doi.org/10.1093/jis/15.2.247

Barth, F. (1998). Ethnic Groups and Boundaries: The Social Organization of Culture Difference. Waveland Press.

Beatty, A. (1999). Varieties of Javanese Religion: An Anthropological Account. Cambridge University Press.

Bell, G. F. (2001). The New Indonesian Laws Relating to Regional Autonomy: Good intentions, Confusing Laws. Asian-Pacific Law \& Policy Journal.

Bellah, R. N. (1991). Beyond Belief: Essays on Religion in a Post-Traditionalist World. University of California Press.

Bluhm, J. E. (1983). A preliminary statement on the dialogue established between the reform magazine al-manar and the malayo-indonesian world. Indonesia Circle. School of 
Oriental \& African Studies. Newsletter. https://doi.org/10.1080/03062848308729564

Boontharm, D. (2003). The Sultanate of Banten AD 1750-1808: A Social and Cultural History.

Chatterjee, P. (1986). Nationalist Thought in the Colonial World: A Derivative Discourse? London: Zed Books for the United Nations University.

Christomy, T. (2008). Signs of Wali: Narratives at the Sacred Sites in Pamijahan, West Java. In Signs of Wali: Narratives at the Sacred Sites in Pamijahan, West Java. https://doi.org/10.26530/oapen_459530

Cranston, M. (1991). The Noble Savage: Jean Jacques Rousseau 1754-1762. University of Chicago Press.

Djajadinigrat, H. (1913). Critische Beschouwing van de Sadjarah Banten: Bijdrage ter Kenstscheteing van de Javaansche Geschiedschrijving.

Djamal, M. (2014). The Origin of the Islamic Reform Movement in Minangkabau Life and Thought of Abdul Karim Amrullah. Studia Islamika. https://doi.org/10.15408/sdi.v5i3.744

Eck, D. L. (2007). Prospects for pluralism: Voice and vision in the study of religion. Journal of the American Academy of Religion. https://doi.org/10.1093/jaarel/lfm061

Eickelman, D. F. (1982). The Study of Islam in Local Context. Contributions to Asian Studies.

Florida, N. K. (1995). Writing the past, inscribing the future: history as prophecy in colonial Java. Duke University Press. 
Formichi, C. (2013). Islam and the Making of the Nation: Kartosuwiryo and Political Islam in 20th Century Indonesia. Leiden: Verhandelingen Van Het Koninklijk Instituut Voor Taal-, Land.

Foulcher, K. (2000). Sumpah Pemuda: The Making and Meaning of a Symbol of Indonesian Nationhood. Asian Studies Review. https://doi.org/10.1080/10357820008713281

Geertz, C. (1960). The Religion of Java. Glencoe, Ill., Free Press. Geertz, C. (1968). Islam Observed: Religious Development in Morocco and Indonesia. Yale University Press.

Geertz, H. (1963). Indonesian cultures and communities. HRAF Press.

Gellner, E. (1983). Nations and nationalism. Cornell University Press.

Guillot, C., Ambary, H. M., \& Dumarçay, J. (1990). The Sultanate of Banten. Gramedia Book Pub. Division.

Hamka. (2010). Ayahku: riwayat hidup Dr. H. Abdul Karim Amrullah dan perjuangan kaum agama di Sumatera (Edisi terk). Pustaka Dini.

Hasan, N. (2007). The Salafi Movement in Indonesia: Transnational Dynamics and Local Development. Comparative Studies of South Asia, Africa and the Middle East. https://doi.org/10.1215/1089201x-2006-045

Hasan, N. (2008). Saudi Expansion, the Salafi Campaign and Arabised Islam in Indonesia. Kingdom Without Borders, Saudi Arabia's Political, Religious and Media Frontiers.

Hidding, K. A. H. (1929). Nji Pohatji Sangjang Sri. Leiden,.

Ho, E. (1997). The Muwalladin," in Ulrike Freitag and William G. Clarence-Smith (eds). Hadrami Traders, Scholars and Statesmen in the Indian Ocean, 1750s-1960s. New York: 
Brill.

Holtzappel, C., \& Ramstedt, M. (2009). Decentralization and regional autonomy in Indonesia: implementation and challenges. Institute of Southeast Asian Studies.

Hourani, A. (1962). Arabic thought in the liberal age, 17981939. Oxford University Press for the Royal Institute of International Affairs.

Iskandar, J., \& Iskandar, B. S. (2017). Various Plants of Traditional Rituals: Ethnobotanical Research Among The Baduy Community. Biosaintifika: Journal of Biology \& Biology Education, 114. https://doi.org/10.15294/biosaintifika.v9i1.8117

Johns, A. H. (1961). Sufism as a Category in Indonesian Literature and History. Journal of Southeast Asian History. https://doi.org/10.1017/S0217781100000260

Jordaan, R. E. (1997). Tara and Nyai Lara Kidul: Images of the Divine Feminine in Java. Asian Folklore Studies, 56(2), 285. https://doi.org/10.2307/1178728

Kimball, C. (2009). When Religion Becomes Evil: Five Warning Signs. New York Harper Collins.

Laffan, M. F. (2007). Islamic Nationhood and Colonial Indonesia: The Umma Below the Winds. Routledge.

Landon, K. P. (1949). Southeast Asia, Crossroad of Religions. University of Chicago Press.

Liu, J. H., Fisher Onar, N., \& Woodward, M. W. (2014). Symbologies, technologies, and identities: Critical junctures theory and the multi-layered nation-state. In International Journal of Intercultural Relations. https://doi.org/10.1016/j.ijintrel.2014.08.012 
Machmudi, Y. (2008). Islamising Indonesia: The Rise of Jemaah Tarbiyah and the Prosperous Justice Party (PKS). ANU Press. https://doi.org/10.22459/II.11.2008

Madjid, N. (1994). Islamic roots of modern pluralism Indonesian experiences. In In: Woodward, M. (ed.) Toward a New Paradigm: Recent Developments in Indonesian Islamic Thought (Vol. 1, Issue 1, pp. 55-77). Gedung Pusat Pengkajian Islam dan Masyarakat (PPIM) UIN Jakarta. https://doi.org/10.15408/sdi.v1i1.866

Mahmud, S. (2008). Kyai Hasyim Asy'ari Trnas. Sebulus Salam Indonesia, Bekasi.

Maskumambang, M. F. (2015). Menolak Wahabi. Depok: Sahifa.

Meijer, R. (n.d.). Global Salafism: Islam's New Religious Movement. Columbia University Press.

Memon, M. (1976). Ibn Taimīya's Struggle Against Popular Religion: With an annotated translation of his Kitāb Iqtid̄ā' aṣ-Sirāt al-Mustaquīm Mukhālafat Aṣ̣āb al-Jahìm. Mouton, The Hague.

Millie, J. (2009). Splashed by the Saint: Ritual Reading and Islamic Sanctity in West Java. Leiden: KITLV Press.

Morfit, M. (1981). Pancasila: The Indonesian State Ideology According to the New Order Government. Asian Survey, 21(8), 838-851. https://doi.org/10.2307/2643886

Muhaimin, A. G. (2006). The Islamic Traditions of Cirebon: Ibadat and Adat Among Javanese Muslims. ANU E Press. https://doi.org/10.22459/isc.11.2006

Nakamura, M. (2012). The Crescent Arises over the Banyan Tree: a Study of the Muhammadiyah Movement in a Central Javanese Town, c.1910s-2010. Institute of 
Southeast Asian Studies.

Noer, D. (1973). The Modernist Muslim Movement in Indonesia, 1900-1942. Singapore: Oxford University Press.

Noorhaidi Hasan. (2006). Laskar Jihad: Islam, Militancy, and the Quest for Identity in Post-New Order Indonesia. Southeast Asia Program Publication.

NU Online. (n.d.). Inilah Kriteria Bid'ah Dhalalah dan Bid'ah Hasanah. 2016.

NU Online. (2011). Ziarah Kubur.

Pigeaud, T. G. T., \& Graaf, H. J. de. (1976). Islamic States in Java 1500-1700. Brill. https://doi.org/10.1163/9789004287006

Raffles, T. S. (1817). The History of Java. London, Black, Parbury and Allen.

Reuter, T. (2009). Globalisation and local identities: The rise of new ethnic and religious movements in post-suharto Indonesia. Asian Journal of Social Science. https://doi.org/10.1163/156848409X12526657425181

Ricklefs, M. C. (2001). A History of Modern Indonesia Since C. 1200. Stanford University Press.

Ricklefs, M. C. (2006). Mystic Synthesis in Java: A History of Islamization from the Fourteenth to the Early Nineteenth Centuries. EastBridge.

Rinkes, D. A. (1996). Nine Saints of Java. [Kuala Lumpur, Malaysia] : Malaysian Sociological Research Institute.

Rohmana, J. A. (2012). Sundanese Sufi Literature and Local Islamic Identity: A Contribution of Haji Hasan Mustapa's 
Dangding. Al-Jami'ah: Journal of Islamic Studies. https://doi.org/10.14421/ajis.2012.502.303-327

Roy, O. (2010). Holy Ignorance: When Religion and Culture Part Ways. New York, Columbia University Press.

Rush, J. R. (2016). Hamka's Great Story: A Master Writer's Vision of Islam for Modern Indonesia. Madison: University of Wisconsin Press.

Sarsito, T. (2006). Javanese culture as the source of legitimacy for Soeharto's government. Asia Europe Journal. https://doi.org/10.1007/s10308-006-0078-y

Sirriyeh, E. (1999). Sufis and Anti-Sufis: The Defense, Rethinking and Rejection of Sufism in the Modern World. Curzon. https://doi.org/10.4324/9781315027388

Skeat, W. W. (1900). Malay magic, being an introduction to the folklore and popular religion of the Malay Peninsula. Macmillan,London.

Smith, B. J., \& Woodward, M. (2016). Magico-spiritual power, female sexuality and ritual sex in Muslim Java: Unveiling the kesekten of magical women. Australian Journal of Anthropology. https://doi.org/10.1111/taja.12140

Soebardi, S. (1983). Kartosuwiryo and the Darul Islam Rebellion in Indonesia. Journal of Southeast Asian Studies. https://doi.org/10.1017/S0022463400009024

Sunyoto, A. (2016). Atlas Wali Songo. LESBUMI PBNU.

Tambiah, S. J. (1997). Leveling Crowds: Ethnonationalist Conflicts and Collective Violence in South Asia. University of California Press.

Thornton, H. (2005). State of nature or Eden? : Thomas Hobbes and his contemporaries on the natural condition of human beings. University of Rochester Press. 
Vickers, A., \& Fisher, L. (1999). Asian Values in Indonesia? National and Regional Identities. Journal of Social Issues in Southeast Asia. https://doi.org/10.1355/sj14-2f

Wahid, A. (2009). Ilusi Negara Islam: Ekspansi Gerakan Islam Transnasional di Indonesia. The Wahid Institute.

Waluyajati, R. S. R. (2017). Agama Djawa Sunda (ADS). Religious: Jurnal Studi Agama-Agama Dan Lintas Budaya. https://doi.org/10.15575/rjsalb.v1i2.1389

Weber, E. (1976). Peasants into Frenchmen: The Modernization of Rural France, 1870-1914. Stanford University Press.

Weintraub, A. N. (1994). Tune, Text, and the Function of Lagu in Pantun Sunda, a Sundanese Oral Narrative Tradition. Asian Music. https://doi.org/10.2307/834389

Wessing, R. (1974). Cosmology and Social Behavior in A West Javanese Settlement. Unpublished Ph.D. Dissertation, Department of Anthropology, The University of Illinois at Urbana- Champaign.

Wessing, Robert. (1988). Spirits of the Earth and Spirits of the Water: Chthonic Forces in the Mountains of West Java. Asian Folklore Studies. https://doi.org/10.2307/1178251

Wessing, Robert. (1993). A change in the Forest: Myth and History in West Java. Journal of Southeast Asian Studies. https://doi.org/10.1017/S002246340000148X

Woodward, M. (1989). Islam in Java: Normative Piety and Mysticism in the Sultanate of Yogyakarta. In Association for Asian Studies Monograph Series. University of Arizona Press. https://doi.org/10.2307/2803920

Woodward, M. (2011). Java, Indonesia and Islam. In Java, Indonesia and Islam. New York: Springer. 
https://doi.org/10.1007/978-94-007-0056-7

Woodward, M. (2014). Jerusalem in Java. In Jerusalem: Conflict and Cooperation in a Contested City (pp. 261-275). Syracuse University.

Woodward, M. (2017). Islam Nusantara: A Semantic and Symbolic Analysis. Heritage of Nusantara: International Journal of Religious Literature and Heritage, 6(2), 181. https://doi.org/10.31291/hn.v6i2.398

\section{Woodward, M., Umar, M. S., Rohmaniyah, I., \& Yahya, M. (2013). Salafi Violence and Sufi Tolerance? Rethinking Conventional Wisdom. Perspectives on Terrorism, 7(6), 58-78.}

${ }^{1}$ On the imagination of French Nationalism and its construction as social reality see:

(Weber, 1976).

${ }^{2}$ On religion and the disintegration of Yugoslavia see: (Kimball, 2009).

${ }^{3}$ In this respect Indonesia resembles Germany, which is officially nearly blind to these differences. It contrasts strongly with Switzerland where they are constitutional principles.

${ }^{4}$ On the establishment of Islam and Muslim kingdoms in West Java see: (Boontharm, 2003; Djajadinigrat, 1913; Pigeaud \& Graaf, 1976; Robert Wessing, 1993).

${ }^{5}$ On cultural inheritance and local identies in West Java see: (Christomy, 2008)

${ }^{6}$ Indonesian state symbology is based on Pancasila (Five Principles) formulated by the country's first president Soekarno on the eve of Independence. It was intended to bring a measure of unity to a vast, diverse ethnoreligious identity space. As Madjid observes, the five principles: 1.) Ketuhanan Yang Maha Esa (Devotion to the allpowerful God), 2.) Kemanusiaan yang adil dan beradab (Just, well-mannered humanism), 3.) Persatuan Indonesia (Indonesian unity), 4.) Kerakyatan yang dipimpin oleh hikmat kebijaksanaan dalam permusyawaratan/perwakilan (Populism/democracy with wise leadership assisted by consultation [with the people] and 5.) Keadilan sosial bagi seluruh rakyat Indonesia (Social justice for all of the Indonesian people) are deconfessionalized versions of common Islamic principles including the unity of God (tawhid) and justice $(a d l)$. There have been many translations of the wording of the Pancasila principles. I have chosen to remain as close as possible to the Indonesian original. On Indonesian discourse about Pancasila see: (Madjid, 1994; Morfit, 1981). 
${ }^{7}$ Rousseau and other European Enlightenment thinkers created the idea of the "noble savage" who supposedly lived in a contented, idyllic state of nature as an alternative to Thomas Hobbes's (1588-1679) proposed state of nature in which life is "solitary, poor, nasty, brutish and short." (Cranston, 1991; Thornton, 2005) There is no empirical evidence to support either of these positions.

${ }^{8}$ On Persatuan Islam See: Federspiel, H. (2009) Persatuan Islam: Islamic Reform In Twentieth Century Indonesia, Singapore: Equinox Publishing. On Muslim Scriptural Arguments Concerning The Authenticity Of These Practices See: (NU Online, 2011)

${ }^{9}$ There are of course individuals engage in both styles of discourse.

${ }^{10}$ On the hierarchical nature of ethnicity and the fuzziness of ethnic boundaries see (Barth, 1998)

11 On Muhammadiyah in Yogyakarta see: (Nakamura, 2012) On Sumatra see: (Djamal, 2014).

${ }^{13} \mathrm{http}$ ://presidenri.go.id/internasional/islam-nusantara-dan-islam-berkemajuan-dariindonesia-untuk-dunia.html

${ }^{14}$ http://www.republika.co.id/berita/dunia-islam/islam-nusantara/15/08/02/nsfsf2318ini-penjelasan-kiai-nu-bagi-penolak-islam-nusantara

15 http://sangpencerah.id/2015/09/langkah-muhammadiyah-berkemajuan-lima.html

${ }^{16} \mathrm{http}: / / \mathrm{www}$. suara-islam.com/read/index/14820/Beda-Islam-Berkemajuan-dengan$\underline{\text { Islam-Nusantara- }}$

${ }^{17}$ Nashir, H. (2017) “Anstomi Gerakan Wahabiyah,” Suara Muhammadiyah. http://www.suaramuhammadiyah.id/2017/05/08/anatomi-gerakan-wahabiyah/ 